\title{
Fueling a Third Paradigm of Education: The Pedagogical Implications of Digital, Social and Mobile Media
}

\author{
John V. Pavlik \\ Rutgers University, United States
}

\begin{abstract}
Emerging technologies are fueling a third paradigm of education. Digital, networked and mobile media are enabling a disruptive transformation of the teaching and learning process. This paradigm challenges traditional assumptions that have long characterized educational institutions and processes, including basic notions of space, time, content, and learning outcomes. Innovative educators have an opportunity to blend face-to-face and digital learning models to advance an engaged, effective, efficient and affordable model of learning in the $21^{\text {st }}$ century. This emerging paradigm includes changes in at least five key teaching and learning dimensions, including the direction of communication, the level of interactivity, the media of communication, the constraints on the educational process, and the learning outcomes. Recommendations for implementing new teaching and learning techniques are offered.
\end{abstract}

Keywords: Digital technologies; Social media; Networked society; Mobile media

\section{Introduction}

Innovative uses of emerging technologies are enabling a fundamental transformation of the teaching and learning process. Fueling this transformation is the confluence of technological developments, the seeds of which were planted more than three decades ago. This article outlines the forces advancing the emerging digital learning paradigm as well as the possible consequences of this fundamental transformation in teaching and learning.

In the early 1980s the author was working on his doctoral dissertation at the University of Minnesota. He spent many hours in a basement office at what was called a "dumb" terminal networked through a dialup modem to a mainframe computer located in another building. The 1200 -baud modem was slow by 2014's gigabit broadband standards. But in terms of speed and ease, it easily beat going offline and using keypunch cards to instruct the mainframe.

Sometimes after a particularly productive day, the author paused in his research for a few minutes to play "Adventure." It was an early online fantasy role-playing game and, importantly to a financially strapped doctoral student, it was free (Wikipedia, 2013a). Adventure had no graphics, just words on an amber screen. But it was interactive. The author typed commands that traveled over the modem and were carried out by his character...go north, pick up the sword, etc. The 
screen displayed verbal descriptions of the results...you've fallen into a pit, you're holding a gold coin.

What made games such as Adventure especially significant in terms of their educational implications was the fact multiple, physically distributed players (known as MMORPGs...a predecessor to today's Massive Open Online Courses, or MOOCs) could interact and play the games collaboratively or competitively (Wikipedia, 2013b). And coming soon was something called a smart terminal, or networked personal computer (PC) (Kline, 1980). These would enable much more, including graphics, sound effects, and multimedia user-generated content (UGC). On the horizon was high-speed, always on network connectivity, or broadband. Even more distant was ubiquitous high-speed, broadband wireless, such as $\mathrm{Wi}-\mathrm{Fi}$, and the miniaturized devices courtesy of Moore's Law to utilize it (Wikipedia, 2013c). But the confluence of these developments would bring dramatic consequences to education. As David J. Helfand (2013) suggests, these developments laid the foundation for a third educational paradigm of engaged learning taking shape three decades later.

In the mid-1980s the educational pioneers such as Wayne Danielson of the University of Texas wrote software for journalism and communication education. These pioneers were developing a wide range of creative digital learning tools such computer algorithms for analyzing student writing and providing instantaneous user feedback in online media simulations. Wayne Danielson of the University of Texas applied artificial intelligence (Al) to create an early tool for generating computer-written haikus. Others such as William Oates of the University of Florida designed and taught online courses and hybrid offerings of online and face-to-face courses. In early the 2000s educational pioneers such as Ann Kirschner helped Columbia University create Fathom, a global, online learning experiment and precursor to today's MOOCs.

\section{Disruptive Innovation in Higher Education}

Yet, none of these early digital innovations was fundamentally transformative or paradigm shifting. As Clayton M. Christensen of Harvard notes, there are two main types of innovations: sustaining and disruptive (Christensen, 2013; Bower \& Christensen, 1995). Early experiments with digital teaching tools offered strategies and techniques to improve education, to make it more efficient and user customized. But they did not disrupt the essential nature of education. These innovations improved the educational process and gave relative advantage to early adopters. But they did not transform the entire educational marketplace or increase its overall value.

Broadly speaking, technology exerts at least four main influences on education: (1) it transforms the methods of teaching and learning; (2) it reshapes the content of what is taught and learned; (3) it transforms educational institutions, structures and costs; and (4) it redefines the relationships between and among students, teachers and educational institutions. Early digital developments had an evolutionary influence on one, two or three of these areas, but paradigm shift requires change in all four. As Thomas Kuhn noted in his seminal work, paradigm shift involves changing the basic assumptions that underlie an entire discipline (1962). 
In this context, the first paradigm of education existed for thousands of years and operated in an age of pre-media technology. It was a form of one-to-one tutoring or mentoring. Mentoring is highly effective from a learning perspective, but it is very expensive, typically requiring one-on-one instruction. It is generally for only the elite. From the time of Aristotle, before the advent of media technology, great teachers mentored their pupils using primarily oral communication.

The second paradigm of education emerged with the advent of analog media technology, especially the printed book in the Middle Ages. It is a model of learning based on one-to-many communication. Put in its simplest terms, it's a broadcasting model of education. A teacher lectures to a group of students assembled in a classroom. Students read printed materials typically outside of class time and complete assignments to facilitate and test their comprehension of course materials. This model is generally less effective than direct mentorship because it suffers from a lack or limited amount of customization and direct feedback. It is relatively cost efficient for mass learning of facts, methods and principles, and was particularly well suited for the immediate Industrial Age where information workers were prized.

In 2014 education is at the dawn of a third paradigm of education. It is defined by interconnectedness among students and teachers and features many-to-many communication and multidirectional mentorship (see Figure 1). The professor is no longer in the role of the grand master of knowledge. Instead, she or he is a mentor and guide, and students engage in a shared process of knowledge exploration and discovery. This paradigm represents the decline of hierarchy in learning. It portends the end of courses. Learning becomes fluid and boundary spanning and interconnected. It is built on crowdsourcing. Learning is a process of mutual exploration and discovery between and among students and the person formerly known as the instructor, adapting Jay Rosen's apt description of the rise of the citizen journalist in the digital age (2012). Reigeluth and Karnopp (2013) have described the essential nature of this paradigm and its implications for schools.

Figure 1. Three Educational Paradigms

\begin{tabular}{|l|l|l|l|l|l|}
\hline Paradigm & Direction & Interactivity & Media & Constraints & $\begin{array}{l}\text { Outco } \\
\text { mes }\end{array}$ \\
\hline Tutoring & One to one & High & $\begin{array}{l}\text { Oral (face to } \\
\text { face) }\end{array}$ & $\begin{array}{l}\text { Time, place, } \\
\text { cost }\end{array}$ & Knowledge \\
\hline Broadcast & $\begin{array}{l}\text { One to } \\
\text { many }\end{array}$ & Limited, low & $\begin{array}{l}\text { Lecture, } \\
\text { Mediated } \\
\text { (book) }\end{array}$ & $\begin{array}{l}\text { Time, place, } \\
\text { content }\end{array}$ & Information \\
\hline Engaged & $\begin{array}{l}\text { Many to } \\
\text { many }\end{array}$ & High & $\begin{array}{l}\text { Hybrid } \\
\text { (personal } \\
\text { tutoring, } \\
\text { online peer } \\
\text { mentoring) }\end{array}$ & $\begin{array}{l}\text { Imagination, } \\
\text { connectivity }\end{array}$ & $\begin{array}{l}\text { Creative } \\
\text { problem } \\
\text { solving, } \\
\text { innovation, } \\
\text { knowledge }\end{array}$ \\
\hline
\end{tabular}


The third paradigm is NOT about subject mastery. Featuring online video learning modules available on an almost unlimited number of subjects, the Khan academy and MOOCs are especially well designed for that. Their value is particularly high when learning analytics and artificial intelligence are used effectively to optimize and customize student engagement and learning in real time (Fournier, 2011). Interactive, on-demand multimedia resources such as the Khan Academy enable students to learn the basics of any discipline asynchronously (Khan Academy, 2013). But they are severely limited in terms of giving the individual student direct, interactive access to the human course instructor. As A. J. Jacobs, editor at large for Esquire magazine, noted after completing three MOOCs: "When it comes to Massive Open Online Courses, like those offered by Coursera, Udacity and edX, you can forget about the Socratic method. The professor is, in most cases, out of students' reach, only slightly more accessible than the pope or Thomas Pynchon. Several of my Coursera courses begin by warning students not to e-mail the professor. We are told not to 'friend' the professor on Facebook" (2013).

Though extremely efficient, MOOCs are still largely an extension of the second educational paradigm, bringing the idea of one-to-many education to an extreme. While an increasing number of MOOCs integrate artificial intelligence and expert systems to provide student feedback and learning customization, the ability of these systems to function effectively is largely limited to courses designed to advance subject matter mastery. They have limited utility where student learning objectives involve developing new knowledge, solving new problems, and innovation.

The emerging third paradigm of education IS about students learning creative problem solving, innovation and generating new knowledge. It embraces a return of mentoring but in a costeffective form. In Industrial Age education most mentoring has been limited to doctoral education, independent studies, and interaction with graduate students. Outside of formal team projects, collaboration among students is sometimes even frowned upon as a form of cheating.

The arrival of the third educational paradigm does not spell the end of the previous paradigms. The rise of the second paradigm did not spell the end of the first paradigm. But it did generally push it to the side, despite the substantial superiority of tutoring. The advance of a third paradigm of education likely will not end the broadcast model of teaching. In fact, MOOCs bring it to an entirely new level of cost effectiveness and global accessibility, and represent an important and valuable form of sustaining innovation. Witness the emerging success of the University of the People, the first tuition-free, fully online four-year university to be granted accreditation (http://www.uopeople.org/).

\section{Hybrid Learning}

One development from the late 1990s worth noting here is hybrid learning. Hybrid courses combine face-to-face instruction and online learning. In one hybrid journalism course the author taught in the late 1990s, students working outside of formal class time could efficiently communicate and collaboratively learn via their electronic group (e-group). They used the e-group to pursue team projects about innovation in news media. Among the topics they explored were 3D printing, augmented reality and an early government big data initiative to build a digital 
surveillance system today called PRISM. Importantly, the e-groups included not just students currently enrolled but many who had previously taken the class and had become alumni, working professionally. These course graduates, so to speak, were still active participants in the class as mentors to current students. Appropriately enough, the students introduced the instructor to the particular e-groups software tool they used for online collaboration.

In this context, course management tools such as Blackboard and eCollege, at least as implemented at most colleges, have a fundamental flaw: each semester students are locked out at the end of the term. Instead, minimizing the potential to achieve maximum cross-generational education, these alumni are blocked as possible mentors to current students. Because these commercial course management systems are linked to the official university registrar, students who sign up for a class are automatically enrolled in the online section, which is a useful efficiency. Those no longer enrolled at the university are deleted from the course e-group roster. This protocol may maximize university revenues and reduce the potential for cheating, but it severely limits the educational potential of online learning. While instructors can request special access be granted to individual alumni or other guests on a case-by-case basis each semester, it adds an administrative impediment to educational-professional engagement.

In the emerging third paradigm, creative problem solving and innovation are the primary learning outcomes. Educators need to develop new assessment methods using the unique capabilities of digital technology, from algorithms to artificial intelligence. These will also help to resolve on a structural level the issue of academic integrity in a digital age.

Entering this third paradigm of education, learning can transcend a variety of constraints that have long hampered education. Philip Long, retired chief information officer for Yale University, notes that innovative educational environments designed for this third paradigm can overcome many traditional learning constraints, including cost and choice (2013). Long argues that the end of these constraints creates an environment for "learning unleashed." It is an educational environment that puts increasing control in the hands of the learner. But it means educators must be willing to relinquish some of that control.

In addition to the constraints Long has identified, the third paradigm also means education can transcend three of the most fundamental educational assumptions: boundaries defined by space (a school), time (a semester) and content (a course). The confluence of networking, geo-location and mobile, wearable technology such as Google Glass and cloud computing can overcome the constraints of place, time and content in education. They can make learning continuous, collaborative and contextualized or connected to the broader world (Wheeler, 2013)

\section{Deeply Engaged Learning}

As suggested by Google's Eric Schmidt and Jared Cohen, the interconnected student can become an active collaborator in a continuous learning process (2013). Mobile technology, including wearable devices such as Google Glass, enables the use of geo-location to foster deeply engaged learning. School has long been bounded by space and time and the physical qualities of student and teacher. Emerging technologies allow student and teacher to transcend these constraints. It's 
worth noting that more than half (56 percent) of adults in the U.S. as of 2013 use a smartphone (Smith 2013). Among youth, the level of smartphone and mobile device is even higher (80 percent among the 18-34 segment, a primary college target group). Notably, smartphone ownership is even higher among the Black/Non-Hispanic (63 percent) and Hispanic (60 percent) population than the White/Non-Hispanic (53 percent). This suggests mobile media may be particularly effective as a teaching and learning platform for minority populations. Of course, these networked digital technologies raise important privacy issues that must be managed in an effective manner to protect students' privacy rights (Douthat, 2013).

\section{New Learning Methods}

Geocaching is a globally popular game of scavenger hunting that has moved efficiently from the analog to the digital age. Geocaching is defined as "a free real-world outdoor treasure hunt. Players try to locate hidden containers, called geocaches, using a smartphone or GPS and can then share their experiences online" (Geocaching, 2014). Bringing this into the educational arena, students could play a game of geocaching where the objectives are to find and advance knowledge and help solve community problems. Educators could incorporate these principles and techniques into their curricula through the fusion of augmented reality, big data and social media.

Augmented reality (AR) is a new medium of communication (Craig, 2013). It has been in development for at least two decades, since Tom Caudell coined the term in 1992 in an application designed to facilitate airplane manufacturing and flight control. It's roots trace much deeper. L. Frank Baum, most well known as the author The Wizard of $\mathrm{Oz}_{z}$, in fact in 1901 described a "character marker" that would overlay information onto wearable displays (Johnson, 2012). AR involves the use of wearable or hand-held technologies to access additional information embedded into other objects but otherwise imperceptible to the individual. For instance, various AR technologies enable the creation of interactive print, where audio, video or animations can be embedded into print images. Software such as Daqri 3D allows the reader of a magazine to point her or his mobile device at an AR enhanced image in the magazine and access the embedded AR content. The National Center for Supercomputing Applications (NCSA) at the University of Illinois in Campaign-Urbana has developed a special AR-enhanced issue of its periodical, Access (NCSA, 2012). The $A R$ content embedded into the magazine includes a variety of $3 D$ data-driven visualizations and animations to illustrate printed 2D scientific images. For example, NCSA has created a 3D animated and interactive AR information graphic built by researchers using "NCSA's Forge to improve computational protein structure modeling." Students can use mobile devices to access the interactive 3D graphic and explore the protein structure in ways previously inaccessible.

AR is not limited to that embedded in print or other media. AR can be geo-located in real-world locations, allowing students to engage their physical world in entirely new ways. In collaboration with Columbia University computer science Professor Steven Feiner, the author developed in the late 1990s real-world AR enhancements described as a "situated documentary" (Höllerer, Feiner, \& Pavlik, 1999). Columbia University students used the geo-location capability of AR to tell and explore stories from the University's past, including the 1968 student strike, Prof. Edwin Armstrong's invention of FM radio, and nuclear physicist Enrico Fermi's early work leading to the Manhattan Project. 
Today, students could use the fusion of digital media and AR to collaboratively study their communities in terms of their own local carbon footprint. Students interested in culture could use this AR fusion to collaboratively report and tell unique local stories to a global audience. Students of paleontology could use AR to study collaboratively dinosaurs in a real-world environment enhanced by $3 \mathrm{D}$ virtual dinosaurs that once roamed that space. Students in $21^{\text {st }}$ century Canada might gain a new understanding of their environment's ancient past by encountering 3D animated versions of the true-life giant camels that once roamed that country (Austen, 2013).

This kinesthetic learning approach builds on a well-established body of educational research called legitimate peripheral participation (LPP) (Wikipedia, 2014a; Wikipedia, 2014b]. In LPP, students engage actively in the real work of a discipline under the mentorship of a faculty member with expertise in the discipline. Students studying history, for instance, might use a variety of mobile devices to conduct community history. They might do oral histories recorded and shared digitally, shooting photographs and video and analyzing the material collected in the context of historical documents and records (Lave \& Wenger, 1991). Such LPP does not supplant rigorous historical investigations by trained historians, but it engages students in a process that both enriches their learning and can contribute, at least peripherally, to the field. Blackboard introduced an AR application to its mobile course management system in 2012. Innovative educators can use this technology to help meet learning objectives in a mobile environment.

Research consistently demonstrates that active, multi-modal learning greatly facilitates student comprehension (Prince, 2004). LPP is just one form of active learning. Other forms can involve wider use of mobile devices. Clickers, for instance, enable students to answer questions posed by the instructor during live class. The instructor can instantly gauge student learning and customize her or his instruction accordingly. Moreover, learning analytics based on such data are increasingly being incorporated across digital learning environments. Mobile devices such as smartphones or tablets can be used easily as well, as clicker apps and other tools for active learning are widely available at low or no cost (Socrative, 2014). This is a strategy to take advantage of many students' natural inclination toward ubiquitous and often non-stop mobile device use. Rather than fight against the tide, so to speak, this is an approach to exploit it for educational benefit.

Active learning via these or other digital devices such as those in MOOCs also provides the instructor with real-time learning analytics. Research shows big data analytics are an effective tool to enable the professor to make instant adjustments to optimize learning and further diagnostics of teaching effectiveness as well as learning assessment (ELI, 2011).

Research further suggests that learning is increasingly a process of social engagement. Steinkueler and Duncan report on a study of players of the popular online game "World of Warcraft" (WoW) (2013). Their investigation shows that the dominant use of the discussion board for WoW is the social construction of knowledge. In fact, in their study almost all posts, 86 percent, revolved around social knowledge construction (Steinkuehler, Martin, \& Ochsner, in press). Game players who posted to the discussion forum would talk with each other, for instance, to develop game playing strategies. A sample WoW forum post illustrates. Wrote one WoW user, "Given your advice, I've spec'd out the following talents..." (post \#4109.29). These findings refute earlier 
educational views, including that scientists construct knowledge in collaborative groups but students do not (Chinn \& Malhotra, 2002). This evidence suggests that social engagement, or peer-to-peer learning, brings important implications for learning in the third paradigm.

The author's own teaching experience over the past two decades confirms these findings. His face-to-face courses employ a hybrid model, with classroom learning supplemented by a studentmoderated discussion board. Students actively engage in social knowledge construction on these boards, asking each other questions, seeking advice and developing new strategies for completing course assignments.

Networked, digital and mobile technologies also provide a window to better engage a diverse student population. In one of the author's hybrid courses, a speech-impaired student was for first time able to fully participate as a peer with her classmates through online text-based discussion. New initiatives are demonstrating the value of digital, wearable devices for providing improved access to educational content for persons with disabilities (Markoff, 2013).

In a fully online course taught asynchronously, one of the author's best students spent the entire semester working and studying at sea. Another semester, an exceptional student stationed in the military and living halfway around the world, was able to fully participate in the online course. In each of these cases, students in an Industrial Age course would not have been able to contribute their enriching, diverse experiences and perspectives to the class. That's not to say there are no drawbacks. Research shows that various non-verbal cues are often either lost or hard to replace in an online learning environment (Hayes, 2011). These non-verbal cues are sometimes critical to comprehension (although there are techniques to introduce non-verbal communication in an online learning environment).

In the years ahead, educators can optimize their instruction with a wide spectrum of digital tools. The New Media Consortium forecasts a variety of emerging technologies will shape education in the near and far term, ranging from MOOCs in the short-term to 3D (or 4D) printing in the longterm (NMC. 2013). E-texts can support collaborative reading and learning. Digital tools using artificial intelligence can enable real-time customization of learning as they are beginning to do with some MOOCs. Merging 3D printing with AR experiences could transform learning. Students studying archeology might not only see a 3D animated version of New York City's $19^{\text {th }}$ century Seneca Village, the community of African-American property owners who once occupied much of the space today filled by Central Park. They could hold and examine in detail 3D physical facsimiles of objects from Seneca Village still in the ground and identified by ground-penetrating radar while visualized in context through AR (Wall, Rothschild, \& Copeland. 2008).

The coalescence of learning analytics and artificial intelligence holds promise. Consider the case of Narrative Science (Northwestern University Innovation and New Ventors Office, 2014). Narrative Science is a commercial venture that grew out of the collaboration of two Northwestern University professors, Kristian Hammond and Larry Birnbaum, and a technology executive, Stuart Frankel. Narrative science "transforms data into stories and insights through its proprietary artificial intelligence authoring system." The algorithms the system uses are highly effective and have attracted dozens of companies, including media enterprises, willing to pay to use the system to write stories. The company's ambition is for the algorithm to write every story for an audience of 
one. Narrative Science's current Al writing tool, Quill, wrote more than a million stories by the end of 2013. It can digest virtually any English-language text and prepare customized digests or summaries based on an $\mathrm{Al}$ analysis. In the future each learner could have access to a customized digital teacher via such an intelligent system.

\section{An Evolving Role for the Educator}

A natural question many educators might ask is "what is the role for human teachers in such an Aldriven environment?" A parallel case is what might be called the canary in the Al wordsmith's cave: news. Algorithm-driven news reporting and writing is already transforming a variety of journalism domains, especially where formulaic approaches are common. Sports reporting, business and finance, medicine and technology are just some of the fields where products such as Narrative Science are already making their mark. Journalists need to adapt and specialize in activities that computers cannot, at least at this time. Reporters need to focus more on rigorous, enterprise and investigative reporting. As journalism scholar Peter Laufer (2013) notes, journalists should slow down. They should take the time to gather all the facts and thoughtfully report them. Laufer explains, "We must eat in order to survive. Accurate information can be another requirement for our survival. Yet our quest for instant information has made it more difficult to find the truth and see the larger picture behind breaking events." Human writing should focus more on the why and the context that underlies a story. Examining why and writing with depth, nuance and rigorous reporting should be the hallmarks of human journalism. As Laufer observes, "We need to ask ourselves what news is important and why." These questions should drive the human journalist.

In the same way, human teachers need to focus on what they can do best. They should not be delivering formulaic materials and presentations. These are best and most efficiently delivered via analytics-driven, Al-enhanced MOOCs and the like. Human teachers should return to the best qualities of the model developed by Aristotle, Socrates and Plato. Human teachers should mentor their students. In particular, human teachers should focus on three domains that can frame all knowledge: 1) ethics (a moral compass), 2) context (the interpretation of knowledge in historical or other context especially the broader stream of a discipline) and 3) critical questioning of assumptions (the fundamental beliefs that underlie any body of knowledge) (de Valck, 2013).

Gaming applies here, as well. Dr. James "Butch" Rosser is a pioneering laparoscopic surgeon and teacher. He has served as the chief of Minimally Invasive Surgery (laparoscopic) at Beth Israel Hospital in New York. While there, he designed and tested a videogame system to teach laparoscopic surgeons the skills they need to perform this delicate procedure. Notably, although laparoscopic surgery is performed via robotic controls while the surgeon watches on a video display, Rosser's game design did not simulate laparoscopic surgery. Instead, it was simply a fun video game that contained embedded in it physical and mental activities that helped surgeons perfect their laparoscopic techniques. Rosser's carefully controlled research demonstrated that his approach could teach laparoscopic surgeons to perform surgeries not only more quickly but also with greater precision (Dobnik, 2004). They operated faster and made fewer errors. It was a win for not only the surgeon but also the patient and the hospital. The hospital improved the quality of its medicine and reduced the likelihood of malpractice suits. Its surgeons could do more 
surgeries in less time without increasing the number of operating rooms. Patients got better surgery performed in less time.

Based on this early experience, Rosser expanded his videogame protocol to other Science, Technology, Engineering and Mathematics, or STEM, fields (science, technology, engineering and mathematics). By 2014, the "playin' to win" approach has been demonstrated effective in a wide spectrum of domains.

\section{Concluding Reflections}

This paper has suggested that emerging technologies are fueling a third paradigm of education. Digital, networked and mobile media are enabling a disruptive transformation of the teaching and learning process. This paradigm challenges traditional assumptions that have long characterized educational institutions and processes, including basic notions of space, time, content, and learning outcomes. Innovative educators have an opportunity to blend face-to-face and digital learning models to advance an engaged, effective, efficient and affordable model of learning in the 21st century. This emerging paradigm includes changes in at least five key teaching and learning dimensions, including the direction of communication, the level of interactivity, the media of communication, the constraints on the educational process, and the learning outcomes.

Recommendations for educational innovation based on this emerging paradigm include the following. First, educators can build on and incorporate digital resources more broadly into teaching at any level and in any field. Live teachers can combine face-to-face mentoring with digital, networked mobile media to create an ongoing virtual classroom community. Second, students can become lifelong learners....and teachers. The line between teacher and student can blur, much as the line between professional journalist and citizen reporter has blurred. In the $21^{\text {st }}$ century, teachers will serve as guide and students will be active participants in a continuous learning process helping to create, discover and share knowledge. This transition is vital because knowledge is advancing at an ever-faster pace and no one person can manage alone. Third, ethics should be the moral compass that guide learning in the digital, networked age. Experienced teachers can play an especially vital role in nurturing the development of this moral compass in their students.

Finally, it is critically important, as Evgeny Morozov warns, to avoid falling into the trap of technology "solutionism" or technological determinism (Morozov, 2013). Technology, no matter how advanced, does not guarantee better education. Nor is it necessarily a pathway to solving any societal problems. Yet, the promise of an engaged community of life-long learners is within sight. To turn this vision into a reality will require the collective effort of a new generation of educational pioneers guided by ethics, a critical lens and the courage to exchange $20^{\text {th }}$ century teaching for $21^{\text {st }}$ century learning. Education should no longer be about going to school or class. In the third paradigm, education can become a process of shared discovery and collaborative and creative problem solving and innovation. It can be available universally for a variety of people at an affordable cost. 


\section{References}

Austen, I. (2013). Canada's north, home to bears, and once, camels. Retrieved on 24 February 2014 from http://www.nytimes.com/2013/03/06/world/americas/camel-fossil-found-in-canadasarctic.html?_r=0.

Bower, J. L. \& Christensen, C. M. (1995). Disruptive technologies: Catching the wave. Harvard Business Review, January-February, 43-53.

Chinn, C.A., Malhotra, B. (2002) Epistemologically authentic inquiry in schools: A theoretical framework for evaluating inquiry tasks. Sci Educ, 86(2): 175-218. doi:10.1002/sce.10001

Christensen, C. M. (2013). Disruptive innovation. Retrieved on 9 June 2013 from http://www. claytonchristensen.com/

Craig, A. (2013). Understanding augmented reality: Concepts and applications. Waltham, MA: Morgan Kauffmann/Elsevier.

de Valck, K. (2013, April). Living and learning in a social media world. Featured presentation at the Technology in Higher Education conference. The Qatar National Convention Center in Doha, Qatar.

Dewey, J. (1897). My pedagogic creed. The School Journal, LIV(3), 77-80.

Dobnik, V. (2004, April 7). Surgeons may err less by playing videogames. Retrieved on 9 June 2013 from http://www.nbcnews.com/id/4685909/ns/technology_and_science-games/t/ surgeons-may-err-less-playing-video-games/\#.UW_fTCtAQ5M

Douthat, R. (2013). Your smartphone is watching you. The New York Times. Retrieved on 2 January 2015 from http://www.nytimes.com/2013/06/09/opinion/sunday/douthat-yoursmartphone-is-watching-you.html?hp

ELI. (2011). Seven Things You Should Know About First Generation Learning Analytics. EDUCAUSE Learning Initiative Briefing. Retrieved on 24 February 2014 from http://www.educause.edu/ library/resources/7-things-you-should-know-about-first-generation-learning-analytics

Fournier, H., Kop, R., \& Sitlia, H. (2011). The value of learning analytics to networked learning on a personal learning environment. Retrieved on 9 June 2013 from file:///C:/Users/User/ Downloads/18150452.pdf

Geocaching. (2014). Geocaching. Retrieved on 24 February 2014 from http://www.geocaching. $\mathrm{com} /$

Hayes, P. Jr. (2013). Nonverbal communication and computer mediated communication to enhance online learning. Retrieved on 9 June 2013 from http://sloanconsortium. org/conferences/2011/aln/nonverbal-communication-and-computer-mediatedcommunication-enhance-online-lear

Helfand, D. J. (2013). The social conquest of general education. Journal of General Education, 62(1), 43.

Hollerer, T., Feiner, S., \& Pavlik, J. (1999, October). Situated documentaries: Embedding multimedia presentations in the real world. In Proc. ISWC '99 (Third Int. Symp. On Wearable Computers, pp. 79-86), San Francisco, CA. 
Jacobs, A.J. (2013). Two cheers for Web U. Retrieved on 9 June 2013 from http://www.nytimes. com/2013/04/21/opinion/sunday/grading-the-mooc-university.html?src=recg\&_r=0

Johnson, J. (2012, September 10). The master key: L. Frank Baum envisions augmented reality glasses in 1901. Mote \& Beam. Retrieved on 9 June 2013 from http://muckrack.com/link/l 380/the-master-key-l-frank-baum-envisions-augmented-reality-glasses-in-1901

Khan Academy. (2013). Retrieved on 9 June 2013 from https://www.khanacademy.org/

Kline, F. G. (1980). Personal conversation with the author. The Research Division of the School of Journalism and Mass Communication at the University of Minnesota.

Kuhn, T.S. (1962). The structure of scientific revolutions. Chicago: University of Chicago Press. ISBN 0-226-45808-3

Laufer, P. (2013). Peter Laufer calls for "slow news revolution". Retrieved on 9 June 2013 from http://www.slownewsmovement. com/2013/01/16/peter-laufer-calls-for-slow-newsrevolution/

Lave, J. \& Wenger, E. (1991), Situated learning: Legitimate peripheral participation. Cambridge University Press. ISBN 0-521-42374-0

Long, P. (2013, April). Learning unleashed: Innovation in teaching and learning achieves critical mass. Featured presentation at the Technology in Higher Education conference at the Qatar National Convention Center in Doha, Qatar.

Markoff, J. (2013, June 5). Device from Israeli start-up gives the visually impaired a way to read. The New York Times. Retrieved on 9 June 2013 from http://www.nytimes.com/2013/06/04/ science/israeli-start-up-gives-visually-impaired-a-way-to-read.html?collection=mostemailed

Morozov, E. (2013). The net delusion: The dark side of internet freedom. Retrieved on 9 June 2013 from http://tropicaline.files.wordpress.com/2011/04/netdelusion.pdf

Northwestern University Innovation and New Ventors Office. (2014). Narrative science. Retrieved on 24 February 2014 from http://invo.northwestern.edu/news/2012/narrative-science

NCSA (2014). Access: Special augmented reality issue, 25(3). Retrieved on 24 February 2014 from http://gladiator.ncsa.illinois.edu/PDFs/access/fall12/access-fall12.pdf

NMC (2014). Horizon report: Higher education edition. Retrieved on 24 February 2014 from http://www.nmc.org/publications/2013-horizon-report-higher-ed

Prince, M. (2004). Does active learning work? A review of the research. Journal of engineering education, 93(3), 223-231.

Reigeluth, C. M. \& Karnopp, J. R. (2013). Reinventing schools: It's time to break the mold. New York: Rowman \& Littlefield Education.

Rosen, J. A. (2012). Most useful definition of citizen journalism. PressThink. Retrieved on 21 May 2012 from http://archive.pressthink.org/2008/07/14/a_most_useful_d.html

Schmidt, E. \& Cohen, J. (013). The new digital age: Transforming nations, businesses, and our lives. New York: Vintage Books. 
Smith, A. (2013). Pew Internet \& American Life Project - Smartphone Ownership 2013. Retrieved on 9 June 2013 from http://www.pewinternet.org/Reports/2013/Smartphone-Ownership2013.aspx

Socrative (2014). Socrative. Retrieved on 24 February 2014 from http://www.socrative.com/

Steinkuehler, C. \& Duncan, S. (2013). Scientific habits of mind in virtual worlds. Journal of Science and Educational Technology. Retrieved on 18 April 2013 from http://website.education. wisc.edu/steinkuehler/papers/SteinkuehlerDuncan2008.pdf

Steinkuehler, C., Martin, C., \& Ochsner, A. (Eds.) (in press). Proceedings of the games, learning, and society conference: Vol. 1. Pittsburgh PA: ETC Press.

Wall, D., Rothschild, N. A., Copeland, C. (2008). Seneca Village and Little Africa: Two African American communities in Antebellum New York City. Historical Archaeology, 42, 97-107.

Wheeler, S. (2013, April). Learning futures: Emerging technologies, pedagogies and contexts. Featured presentation at the Technology in Higher Education conference at the Qatar National Convention Center in Doha, Qatar.

Wikipedia (2013a). History of massively multiplayer online role playing games. Retrieved on 9 June 2013 from https://en.wikipedia.org/wiki/History_of_massively_multiplayer_online _games

Wikipedia (2013b). Massively multiplayer online role-playing game. Retrieved on 9 June 2013 from http://en.wikipedia.org/wiki/Massively_multiplayer_online_role-playing_game

Wikipedia (2013c). Moore's law. Retrieved on 9 June 2013 from http://en.wikipedia.org/wiki/ Moore\%27s_law

Wikipedia (2014a). Kinesthetic learning. Retrieved on 24 February 2014 from http://en.wikipedia. org/wiki/Kinesthetic_learning

Wikipedia (2014b). Legitimate peripheral participation. Retrieved on 24 February 2014 from http://en.wikipedia.org/wiki/Legitimate_peripheral_participation

Correspondence: John V. Pavlik, Professor, Department of Journalism and Media Studies, School of Communication and Information, Rutgers University, New Brunswick, New Jersey, United States. 